\title{
Does degeneration or genetic conflict shape gene content on UV sex chromosomes?
}

\author{
SARAH B. CAREY $Y^{1, \S, *}$ LESLIE M. KOLLAR ${ }^{1, *} \&$ STUART F. MCDANIEL ${ }^{1,2}$ \\ ${ }^{1}$ Department of Biology, University of Florida, Gainesville, FL, USA \\ ${ }^{\S}$ Current address: Department of Crop, Soil, and Environmental Sciences, Auburn University, Auburn, AL, USA \\ Current address: HudsonAlpha Institute for Biotechnology, Huntsville, AL, USA \\ (ㄴ) https://orcid.org/0000-0002-6431-0660 \\ *Current address: Department of Plant Biology, Michigan State University, East Lansing, MI, USA \\ (1) http://orcid.org/0000-0001-8726-9085 \\ ${ }^{2}$ "="stuartmcdaniel@ufl.edu, 이ttps://orcid.org/0000-0002-5435-7377
}

\begin{abstract}
Studies of sex chromosomes have played a central role in understanding the consequences of suppressed recombination and sex-specific inheritance among several genomic phenomena. However, we argue that these efforts will benefit from a more rigorous examination of haploid UV sex chromosome systems, in which both the female-limited (U) and male-limited (V) experience suppressed recombination and sex-limited inheritance, and both are transcriptionally active in the haploid and diploid states. We review the life cycle differences that generate UV sex chromosomes and genomic data showing that ancient UV systems have evolved independently in many eukaryotic groups, but gene movement on and off the sex chromosomes, and potentially degeneration continue to shape the current gene content of the U and V chromosomes. Although both theory and empirical data show that the evolution of UV sex chromosomes is shaped by many of the same processes that govern diploid sex chromosome systems, we highlight how the symmetrical inheritance between the UV chromosomes provide an important test of sex-limited inheritance in shaping genome architecture. We conclude by examining how genetic conflict (over sexual dimorphism, transmission-ratio distortion, or parent-offspring conflict) may drive gene gain on UV sex chromosomes, and highlight the role of breeding system in governing the action of these processes. Collectively these observations demonstrate the potential for evolutionary genomic analyses of varied UV sex chromosome systems, combined with natural history studies, to understand how genetic conflict shapes sex chromosome gene content.
\end{abstract}

Key words: UV sex chromosomes, bryophytes, algae, genetic conflict, speciation

\section{Introduction}

On this $50^{\text {th }}$ anniversary of the International Association of Bryology, we look back another five decades to the very beginnings of genetics and a remarkable period of discovery in bryology. During this time, the first sex chromosomes documented in plants were found in the liverwort Sphaerocarpus donellii (Allen 1917) and (Heitz 1928) coined the now ubiquitous term "heterochromatin" for the dark-staining, heteromorphic sex chromosomes in mosses (reviewed in Reski 1998; Anderson 2000; Berger 2019). More recent work on sex chromosomes has led to key discoveries regarding fundamental genetic processes such as recombination and gene dosage (Muller 1932; Begun \& Aquadro 1992). However, nearly all this subsequent foundational work has focused on species with XY and ZW sex chromosomes like in Dipterans, Lepidopterans, Mammals, Birds, and few seed plants, diverse organisms that nevertheless do not reflect the complete diversity of sex chromosomes. Many bryophytes and algae possess UV sex chromosomes, which are shaped by distinct evolutionary processes (reviewed in Bachtrog et al. 2011; McDaniel \& Perroud 2012; Renner et al. 2017; Coelho et al. 2018). Only in the past few years have researchers brought new experimental tools to observations first made more than a century ago to explore the untapped potential of comparative genomic analyses among haploiddioecious organisms.

The purpose of this review is to highlight the novel insights into genome evolution that can be gained by studying UV sex chromosomes. We first present the two-locus model for the evolution of sex chromosomes in the context of a UV system. Next we describe how the symmetry of U and V sex chromosome transmission alters established expectations for several central molecular population genetic parameters, including recombination, effective population 
size, dosage, and the accumulation of deleterious mutations, relative to XY or ZW chromosome systems. In the third section, we focus on one of the key unanswered questions in sex chromosome evolution-what are the roles of various forms of genetic conflict, like sexual dimorphism, sex-ratio bias, and parent-offspring conflict, in driving differences in the evolution of sex chromosome gene content? We conclude by highlighting how this framework provides a clear motivation for combining bryophyte genomics with systematic natural history observations and classical genetic analysis.

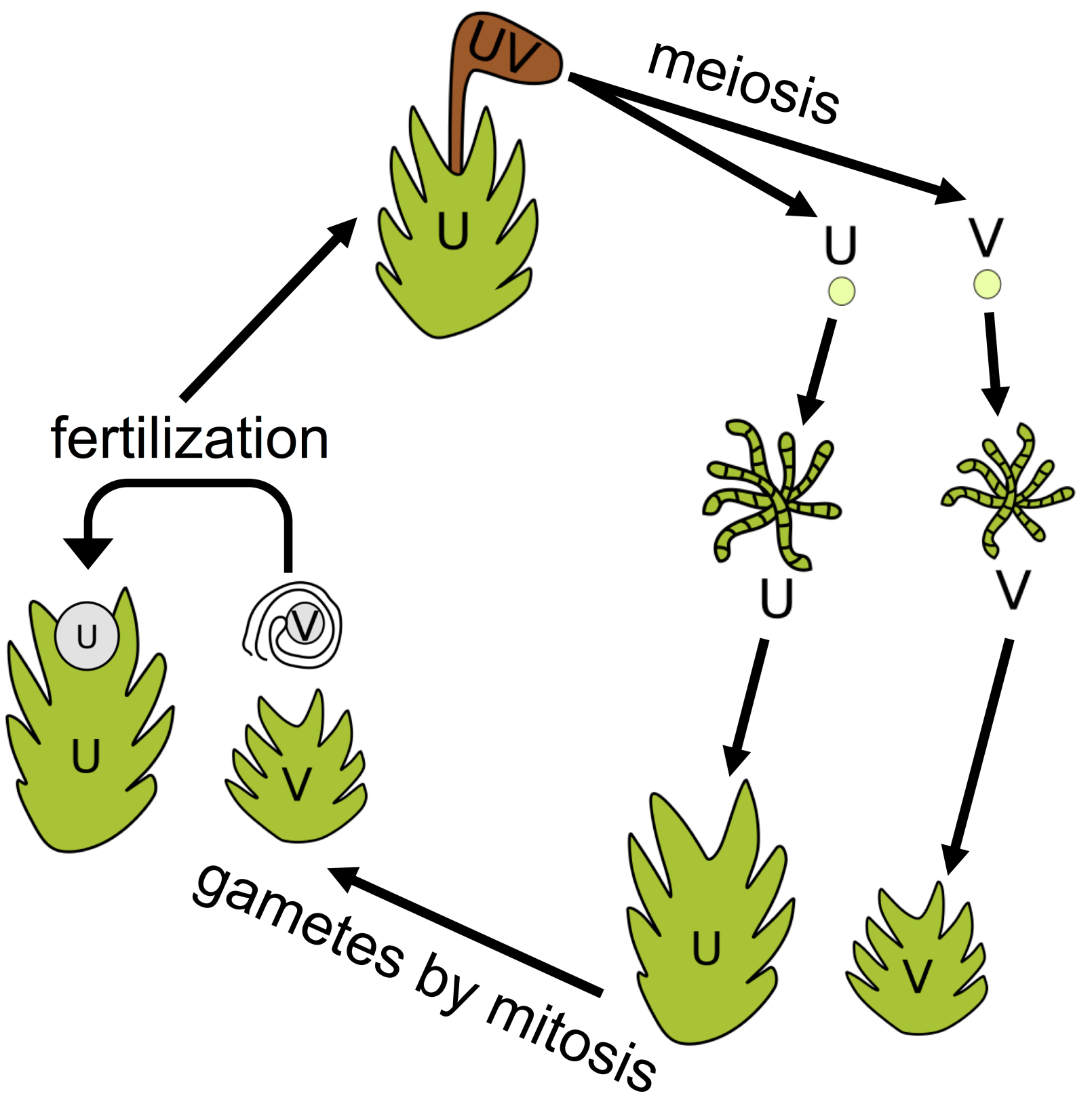

FIGURE 1. Life cycle of a dioecious moss. In mosses, the products of meiosis are haploid spores. For dioecious species, meiosis also segregates the $\mathrm{U}$ and $\mathrm{V}$ sex chromosomes in females and males, respectively. The spores germinate and produce protonemal filaments, upon which gametophores will develop. Because they are haploid, the mature male and female gametophytes produce gametes by mitosis. A V-containing sperm fuses with a U-containing egg, undergoing fertilization, and a diploid embryo (sporophyte) will develop on the maternal plant. The sporophyte embryo has both $\mathrm{U}$ and $\mathrm{V}$ sex chromosomes, but is considered a non-sexed stage, and within which the spores are produced. 


\section{The evolution of UV sex chromosomes from a hermaphroditic ancestor}

All eukaryotes alternate between haploid and diploid stages in their life cycle. Meiosis reduces the genome to a haploid state, while fertilization restores it to diploid. Fertilization, of course, results from the fusion of two gametes, typically called sperm and egg in anisogamous species. In species with separate males and females, the segregation of a chromosome pair often determines sex. Where in the life-cycle sexual differentiation occurs varies among lineages [BOX 1]. In organisms with dioecy in the diploid stage, the sex chromosomes are referred to as either XY or ZW, depending on which sex is heterogametic, while in haploid systems the sex chromosomes are always UV (Fig.1 Bachtrog et al. 2011). The sex chromosome systems share much in common with one another, but the differences among them can shed light on important evolutionary processes.

Sex chromosomes are widely believed to evolve from ordinary autosomes, and may first evolve in concert with dioecy. The evolution of genetically-determined dioecy from a hermaphroditic ancestor requires linked male and female-sterility mutations (Westergaard 1958; Charlesworth \& Charlesworth 1978 but see (Akagi et al. 2014; Müller et al. 2020) for alternative routes). In the standard diploid formulation of this model, a recessive, male-sterility mutation (i.e., one that renders a hermaphrodite effectively a female) can increase in frequency in a hermaphroditic population when inbred offspring are only half as fit as outbred offspring. That is, if inbreeding is deleterious, male sterility may be favored because the increase in maternal fitness compensates for the loss of fitness through paternity. This produces a gynodioecious population containing females and hermaphrodites (Fig. 2A). Such populations are widely known in angiosperms (Dufaÿ et al. 2014; Renner 2014), but to our knowledge have not been experimentally verified in bryophytes.

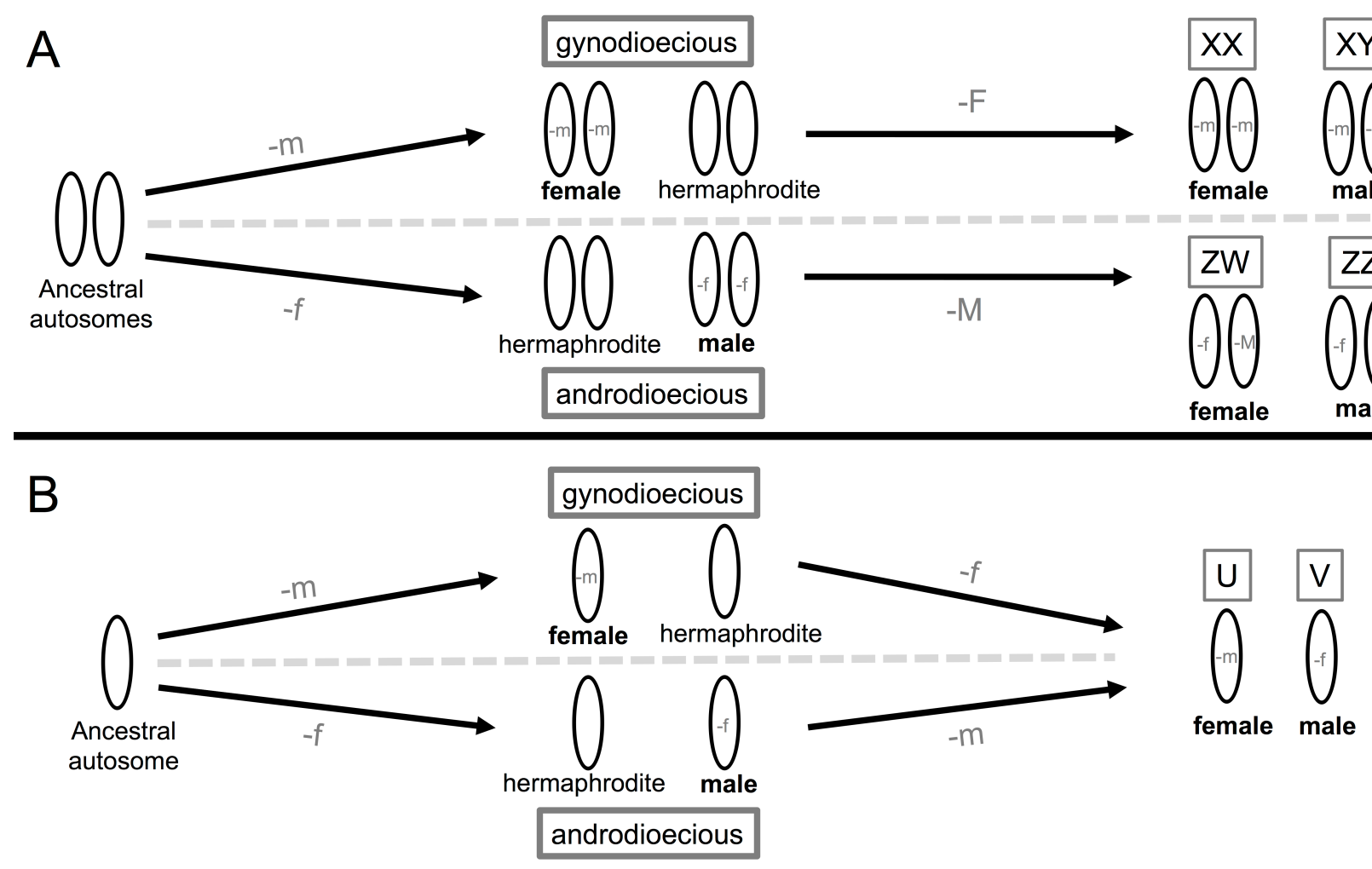

FIGURE 2. Two-locus model for the evolution of XY, ZW, and UV sex chromosomes. For diploid sex chromosomes (A) that originate from an ancestral pair of autosomes, a recessive male-sterility mutation (-m) first evolves, making a gynodioecious population (females and hermaphrodites). From the gynodioecious population a dominant female-sterility mutation (-F) arises making males. Once recombination is suppressed between these sex-determining loci, sex chromosomes are formed. This pathway leads to an XY sex chromosome system. If from an ancestral autosomal pair, a recessive femalesterility mutation (-f) evolves first, making an androdioecious population, followed by a dominant male-sterility mutation $(-\mathrm{M})$, the result is a ZW sex chromosome system. In contrast in haploid sex chromosome evolution (B), if a male or female-sterility mutation evolves first, followed by sterility mutation of the opposite sex, the result is always a UV sex chromosome. 
In a diploid gynodioecious population, a dominant, female suppressor (i.e., a proto-Y chromosome) can increase in frequency, provided that a) it has compensatory effects on male fitness and b) its inheritance is negatively correlated with the male-sterility mutation (now the proto-X chromosome). The fixation of both mutations produces a fully dioecious population with an XY sex chromosome system (Fig. 2A). The conditions under which a female-sterility mutation evolves first, leading to an androdioecious population, are more restrictive. In this case dioecy occurs following the evolution of a dominant, male suppressor (i.e., a proto-W chromosome; Fig. 2A). Recombination between the sterility factors produces some individuals that have both male and female-sterility factors. Because these individuals cannot contribute to subsequent generations, these circumstances favor the evolution of suppressed recombination between the sterility loci, completing the transformation of an autosome into a sex chromosome.

We should point out two important differences between the diploid and haploid formulations of the two-locus model. First, both the androdioecy and gynodioecy pathways lead to the evolution of UV sex chromosomes (Fig. 2B). Like diploid systems, we expect that gynodioecious mating systems should be more frequent than androdioecious systems, but we know of no rigorous evaluation of the frequencies of such systems in any haploid mating species. Second, because the sexes are haploid, dioecy in a UV system can evolve without a dominant male or female suppressor, because dominance is irrelevant in a haploid system. Given that the evolution of a UV system does not depend on the occurrence of rare dominant mutations, unlike both XY and ZW systems, UV systems might evolve more readily than their diploid counterparts (McDaniel et al. 2013; Villarreal \& Renner 2013; Laenen et al. 2016). Interestingly, most UV systems that have been studied to date are quite old (Ahmed et al. 2014; Bowman et al. 2017; Carey et al. 2020). This is of course not to say that they have been static-these data do not preclude turnover events in which a new chromosome "captures" the sex-determining locus, or the formation of neo-sex chromosomes through translocations (Vicoso 2019)but they do suggest these lineages have experienced a long, uninterrupted history of dioecy.

\section{BOX 1: UV sex chromosomes are found in haploid-dioecious life cycles}

In animals and vascular plants with genetically-determined separate sexes, sexual differentiation occurs in the diploid stage of the life cycle. Therefore, the karyotypic sex of an individual is determined by the genotype at fertilization. In the XY system, the fusion of Y-bearing sperm with an X-bearing egg produces a male zygote (the heterogrametic sex), while the fusion of an X-bearing sperm with an X-bearing egg produces a homogametic, female zygote. In the $\mathrm{ZW}$ system, in contrast, the female is the heterogametic sex. In these diploid systems, the non-recombining $\mathrm{Y}$ and $\mathrm{W}$ chromosomes are sex-specific (i.e., transmitted only through the male or female line, respectively), while the $\mathrm{X}$ and $\mathrm{Z}$ are shared between both sexes and freely recombine, much like an autosome, in the homogametic sex. In both the XY or ZW systems, sexual differentiation is a diploid phenomenon.

In other multicellular lineages, including the Phaeophytes (brown algae), Rhodophytes (red algae), Chlorophytes (Ulvophyceae and Chlorophyceae green algae), and Bryophytes (mosses, liverworts, and hornworts), sex determination occurs in the haploid stage of the life cycle. As such, only one copy of a sex chromosome is present during sex expression, with individuals inheriting the $\mathrm{U}$ correlating with females and $\mathrm{V}$ with males, and making both the $\mathrm{U}$ and V sex-specific (Bachtrog et al. 2011). Indeed, since the sexes are already haploid, gametes are produced by mitosis not meiosis (Fig. 1). Fertilization of a U-linked egg and a V-linked sperm produces a zygote that is monomorphic (i.e., non-sexed) and heterozygous at the sex determining factor (homozygous UU or VV sporophytes are not formed in typical matings). In the mature diploid individual, the $\mathrm{U}$ and $\mathrm{V}$ pair at meiosis and segregate independently into females and males (Bachtrog et al. 2011).

The $\mathrm{U}$ and $\mathrm{V}$ chromosomes are in some ways similar to mating-type (MT) loci found in fungi, algae, and other protists (e.g., (Ferris et al. 2010; Bazzicalupo et al. 2019). In these organisms, however, the gametes bearing alternate MT are not phenotypically distinct from one another (i.e., isogamous) and therefore do not have defined sexes (Fig. 3). Thus, while MT loci provide valuable systems for studying the evolution of suppressed recombination in the absence of anisogamy (Branco et al. 2017; Bazzicalupo et al. 2019), we restrict our focus here to true UV sex chromosomes.

\section{Symmetry in sex chromosome transmission alters evolutionary patterns}

The fundamental differences between XY/ZW and UV sex chromosomes stem from the symmetrical transmission of $\mathrm{U}$ and $\mathrm{V}$ compared to the asymmetry of $\mathrm{X}$ and $\mathrm{Y}$ or $\mathrm{Z}$ and $\mathrm{W}$ (Table 1). The most obvious implications of symmetry 
in transition are in the expected amount of segregating variation on the sex chromosomes. In diploid systems, each mated pair has three copies of an $\mathrm{X}$ or $\mathrm{Z}$ chromosome compared to four copies of each autosome and only one $\mathrm{Y}$ or W. Thus, the baseline expected effective population size $\left(N_{e}\right)$ for a X or Z-linked locus is $3 / 4$ of an autosome and a $Y$ or W-linked locus is $1 / 4$ (Bachtrog et al. 2011). In haploid-dioecious systems, each mated pair has one $\mathrm{U}$ and one $\mathrm{V}$ for every two autosomes so both the $\mathrm{U}$ and the $\mathrm{V}$ chromosomes are expected to have $1 / 2 N_{e}$ of an autosome (McDaniel et al. 2013). Thus, in UV systems males and females may have similar amounts of sex-linked genetic variation on which selection can act, while in diploid systems the sexes are expected to have different amounts. We should point out that demographic realities, including differential variance in reproductive success between the sexes (Charlesworth 2009), for example due to deviations from an equal ratio of males to females, or variance in female reproductive output (Bengtsson \& Cronberg 2009), may dramatically alter the patterns of $N_{e}$ in sex chromosomes relative to the autosomal expectation.

Regions of suppressed recombination, like sex chromosomes, also generally have lower than expected levels of diversity due to selective sweeps and background selection, which remove variation across these linked regions (reviewed in Sayres 2018). In XY/ZW systems, suppressed recombination is confined to the male-specific $\mathrm{Y}$ or the female-specific W chromosomes. In contrast, in UV systems, suppressed recombination is present on both the femalespecific $\mathrm{U}$ and male-specific $\mathrm{V}$ chromosome (Table 1). Thus, both the male and female-specific chromosomes are expected to experience an equivalent decrease in nucleotide diversity as consequence of suppressed recombination, barring differences in mutation rate or the strength of selection between the sexes. In addition to reduced genetic variation, suppressed recombination can cause genes on the non-recombining chromosome to respond slower to selection (positive or negative Comeron et al. 2008; Hough et al. 2017). Consequently, such regions may show decreased codon bias (relative to autosomes) and an increase in transposable element (TE) abundance, which in UV systems, is expected to affect both equally, in contrast to the asymmetry in diploid systems (Table 1).

TABLE 1. Comparison of XY, ZW, and UV characteristics.

\begin{tabular}{|c|c|c|c|c|c|c|}
\hline Characteristic & $\mathbf{X}$ & $\mathbf{Y}$ & $\mathbf{Z}$ & $\mathbf{W}$ & $\mathbf{U}$ & $\mathbf{V}$ \\
\hline Inheritance pattern & $\mathrm{M}$ and $\mathrm{F}$ & M & $\mathrm{M}$ and $\mathrm{F}$ & $\mathrm{F}$ & $\mathrm{F}$ & M \\
\hline Hemizygosity & M & M & $\mathrm{F}$ & $\mathrm{F}$ & $\begin{array}{l}\text { diploid } \\
\text { phase }\end{array}$ & $\begin{array}{l}\text { diploid } \\
\text { phase }\end{array}$ \\
\hline $\begin{array}{c}\text { Expected } N_{e} \text {, relative to } \\
\text { autosomes }\end{array}$ & $3 / 4$ & $1 / 4$ & $3 / 4$ & $1 / 4$ & $1 / 2$ & $1 / 2$ \\
\hline Suppressed recombination & NA & Yes & NA & Yes & Yes & Yes \\
\hline $\begin{array}{c}\text { TE content, relative to } \\
\text { autosomes }\end{array}$ & similar & higher & similar & higher & higher & higher \\
\hline $\begin{array}{c}\text { Gene density, relative to } \\
\text { autosomes }\end{array}$ & similar & lower & similar & lower & lower & lower \\
\hline Gene-content bias & $\begin{array}{l}\text { NA, F, or M- } \\
\text { biased }\end{array}$ & M-biased & $\begin{array}{l}\text { NA, F, or } \\
\text { M-biased }\end{array}$ & F-biased & F-biased & M-biased \\
\hline
\end{tabular}

Males (M); females (F); Effective population size $\left(N_{e}\right)$; Transposable elements (TE)

The decreased response to selection in non-recombining regions can promote the accumulation of deleterious mutations and loss of functional genes, a process referred to as degeneration (Charlesworth \& Charlesworth 2000). In addition, because $\mathrm{Y}$ and $\mathrm{W}$ chromosomes are always heterozygous with the $\mathrm{X}$ and $\mathrm{Z}$, respectively, recessive deleterious mutations are sheltered from purifying selection. In UV sex chromosomes, because the diploids are always UV (not UU or VV; Fig. 1\&2) the exposure to selection is symmetrical between the male and female chromosome (Immler \& Otto 2015). Indeed, since the sex chromosomes are both expressed in haploids, UV sex chromosomes overall should 
degenerate slower than either $\mathrm{Y}$ or $\mathrm{W}$ chromosomes (Table 1). Of course, a haploid-expressed gene could degenerate on one of the sex chromosomes - for example, a gene specifically involved in sperm production which is incorporated into the UV non-recombining region is likely to experience strong purifying selection in males where its function is critical, but weak purifying selection on the female $U$ chromosome if its function may be superfluous (Table 1). Nevertheless, we have no a priori reason to expect that the $\mathrm{U}$ or $\mathrm{V}$ sex chromosome should degenerate more than the other. The sparse data for UV systems largely support these predictions. [BOX 2]

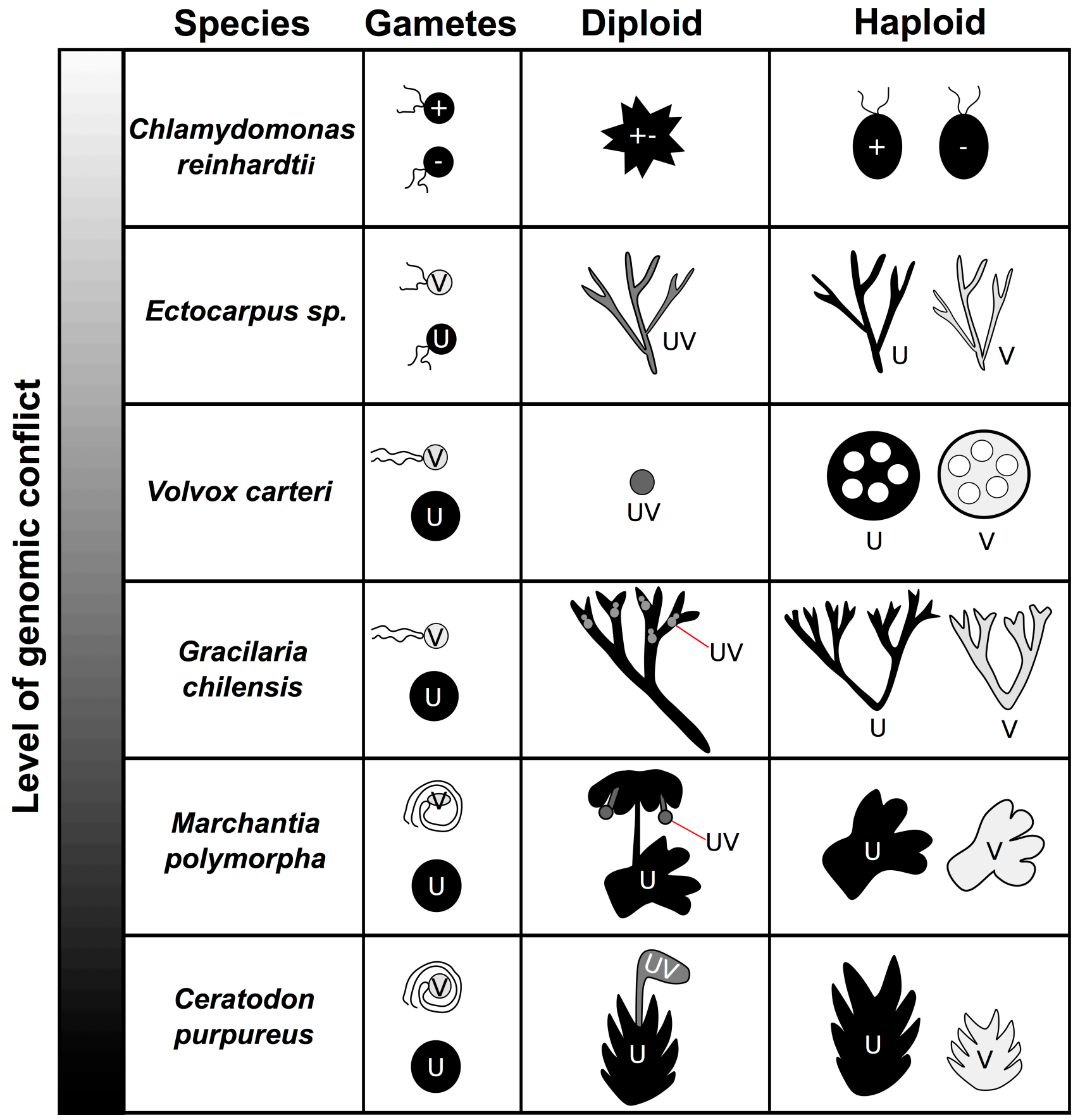

FIGURE 3. Predicted intensity of genomic conflict among UV systems. The level of genomic conflict is lower in matingtype loci because they do not have separate sexes, and therefore lack sexual dimorphism and parent-offspring conflict, although the mating type loci could experience transmission-ratio distortion. Across UV systems, the level of genomic conflict increases as the number or intensity of conflicts increases. Sexual dimorphism tends to be limited in algaes and is but may be obvious in bryophytes. Parent-offspring conflict requires a nutritional dependence between the embryo and the maternal plant, which is absent in some algae but lengthy in some mosses. Transmission ratio distortion is possible in all systems, although distorter systems may be more frequent in outbreeding species. We should note that this graphic is simply meant to illustrate a hypothesis, and that each of these groups is likely to be highly heterogeneous for the forms of conflict that we have depicted. 
The lack of degeneration on UV sex chromosomes influences the potential for dosage compensation, a common feature of XY/ZW systems. In diploid systems, the homogametic sex has two copies of either an X or Z, and therefore two copies of sex-linked genes to express. The heterogametic sex, in contrast, may have only one gene copy if the $\mathrm{Y}$ or $\mathrm{W}$-linked copies have been lost. The gene expression imbalance for X or Z-linked genes that lack a Y or W homolog, due to degeneration, can cause developmental problems or a variety of genetic disorders. Such problems are averted by various forms of dosage compensation, in which one copy of many X-linked genes is silenced in females or the expression of X-linked genes is doubled in males. In contrast, the sex chromosome composition of all life stages is balanced in the UV system-the haploids are either U or V, and the diploids are homogeneous (Fig. 1). If only sexspecific genes are lost on $\mathrm{U}$ and $\mathrm{V}$ chromosomes, and these genes are not expressed in the unsexed diploid phase, then dosage compensation is unlikely to evolve. While dosage compensation in diploid sex chromosomes is highly variable, and even may be absent or incomplete (reviewed in (Mank 2013)), there is no expectation for any such compensation in haploid systems.

\section{BOX 2: Genomic analyses of UV systems}

A growing number of genomic analyses of UV sex chromosomes systems (reviewed in Coelho et al. 2018) provide a foundation for comparative analyses between haploid and diploid sex chromosome systems (Table 1). One of the best genomically studied UV systems to date is the brown algae Ectocarpus sp. An ancestral-state reconstruction of sexual condition in brown algaes found dioecy evolved near the origins of this lineage (Luthringer et al. 2014) and molecular evidence indicates Ectocarpus and the kelps (Laminariales) may share a common UV system that evolved at least 80-110 million years ago (MYA) (Lipinska et al. 2017) The U and V chromosomes in Ectocarpus sp. are relatively small (0.93 and 0.92 megabases $(\mathrm{Mb}$ ) of the $205 \mathrm{Mb}$ genome, respectively; (Ahmed et al. 2014). The non-recombining portions of the $\mathrm{U}$ and $\mathrm{V}$ have similar numbers of genes at 22 and 20, respectively, and share 11 homologous genes (Ahmed et al. 2014). Avia et al. (2018) found the Ectocarpus U and V-linked loci had an $N_{e}$ about $1 / 2$ the autosomal average, suggesting these chromosomes experience levels of selection similar to autosomal loci (Avia et al. 2018). As a result of suppressed recombination, the sex chromosomes show decreased codon bias (Lipinska et al. 2017) and increased TEs relative to autosomes in both sex-determining and pseudoautosomal regions (Ahmed et al. 2014; Luthringer et al. 2015). Consistent with the effects of degeneration, Lapinska et al. (2017) found evidence of gene loss from the ancestral brown algae sex chromosome, in addition to gene gain and gene movement to the autosomes (Lipinska et al. 2017).

Within the chlorophyte green algae, at least two UV sex chromosome systems evolved independently. Dioecy and MT loci evolved in the ancestor of the volvocine algae, including Gonium pectorale, Volvox carteri, and Chlamydomonas reinhardtii at least 200 MYA (Herron et al. 2009; Hamaji et al. 2016). Although, strictly speaking, only Volvox possess anisogamy and therefore true UV sex chromosomes, we mention the other species because the MT chromosomes and UV sex chromosomes are clearly homologous. The Volvox $\mathrm{U}$ and V are 1.51 and 1.13 of the $131 \mathrm{Mb}$ genome and also have similar numbers of genes at 55 and 60, respectively, 50 of which are homologs between the two (Ferris et al. 2010). Consistent with the effects of suppressed recombination, the Volvox sex chromosomes have accumulated TEs (Ferris et al. 2010) and comparisons between Gonium, Chlamydomonas, and Volvox found evidence for gene loss (Hamaji et al. 2016). A second UV sex chromosome evolved in the lineage including Ulva partita (Yamazaki et al. 2017). The 1.5 Mb Ulva U (referred to as MT+) and 1.0 Mb V (referred to as MT-) have some asymmetry in gene numbers with 67 and 46 genes, respectively, and share 23 homologs. While the size of the Ulva partia genome is currently unknown, the recent Ulva mutabilis genome is $98.5 \mathrm{Mb}$ and U. partia may be similar (De Clerck et al. 2018). The discovery of sex-linked PCR markers in red algae (Guillemin et al. 2012), suggests that UV sex chromosomes independently evolved in this group too, but genomic analyses are currently lacking.

Within the bryophytes, more than half of the approximately 20,000 described species are dioecious. Heteromorphic sex chromosomes have been observed using cytological methods in 16 unrelated genera (Allen 1945; Renner et al. 2017) and sex-linked molecular markers have been tested in several additional species (McLetchie \& Puterbaugh 2000; McDaniel et al. 2007; Korpelainen et al. 2008; Baughman et al. 2017). Ancestral-state reconstructions of sexual condition first showed that bryophyte sex chromosomes may have ancient origins (McDaniel et al. 2013; Laenen et al. 2016) and emerging phylogenomic data support in liverworts they evolved at least 400 MYA and in mosses 300 MYA (Carey et al. 2020).

To date, the best studied bryophyte UV sex chromosomes are in the liverwort Marchantia polymorpha. The 4.37 


\section{The role of genetic conflict in the expansion of UV chromosome systems}

The population genetic processes that we have discussed so far suggest that sex chromosome evolution follows a well-circumscribed path. This view masks the diversity in sex chromosome size and gene content that is found among, and even within, many lineages of eukaryotes (Bull 1983; Tree of Sex Consortium 2014; Furman et al. 2020). Clearly degeneration may not play a major role in the evolution of gene content on UV chromosomes, suggesting that other factors, potentially related to life history, may explain variation in sex chromosome size. We should point out that we are focusing only on the non-recombining, sex-limited portions of the sex chromosomes, which may be flanked by psuedoautosomal regions that also vary in size, and experience a host of related but distinct evolutionary processes (Otto et al. 2011).

Surveying the UV species that have been studied so far (Box 2), the proportion of the genome residing on the sex chromosomes ranges from $>1 \%$ in the brown algae Ectocarpus, $\sim 1 \%$ in the green algae Volvox, $\sim 2 \%$ in the liverwort Marchantia, and as high as 30\% of the genome size in the moss Ceratodon (Ferris et al. 2010; Ahmed et al. 2014; Bowman et al. 2017; Carey et al. 2020). It is possible that the variation in UV sex chromosome size is simply a consequence of different patterns of degeneration, like the accumulation of TEs. However, based on the data currently available, each of these UV pairs shows a similar proportion of shared versus sex-specific genes $(\sim 1 / 2$ in Ectocarpus, Volvox, and Ceratodon; $\sim 1 / 4$ in Marchantia; Box 2). If degeneration were the cause of gene number variation, older UV systems should have a greater proportion of sex-specific genes. Instead, the similar proportion of shared genes suggests that a $\mathrm{U}$ chromosome that currently possesses more genes overall, for example from Ceratodon, also lost more homologs that it used to share with the $\mathrm{V}$, meaning that degeneration does not explain the lower gene number in Marchantia or Ectocarpus. Instead, the size of the sex-limited portion of the $\mathrm{U}$ and $\mathrm{V}$ chromosomes within a species shows a remarkable correspondence with potential for new mutations to have different fitness effects in males and females, based on the life history of each species (Fig. 3).

If we consider the fate of a new mutation that increases the fitness of females more than males (i.e., a sexually antagonistic allele), that mutation has a greater chance of increasing in frequency if it is tightly linked to a $\mathrm{U}$ or $\mathrm{W}$ chromosome compared to an autosome (Rice 1987). Conversely, a male-beneficial allele is more likely to fix in a population if it is linked to a $\mathrm{V}$ or $\mathrm{Y}$ chromosome. Mutations that tighten the linkage between sexually antagonistic alleles and the sex-determining region, such as chromosomal inversions, translocations, or expansions of heterochromatin, also have a greater chance of fixing. Despite the intuitive appeal of this mechanism to explain the evolution of sex linkage, the forces that drive the expansion of regions of suppressed recombination on sex chromosomes remain poorly understood (Ironside 2010). If sexual antagonism is a major force driving the evolution of non-recombining sex chromosomes, then species that experience more sexual antagonism should have more gene-rich sex chromosomes.

Three major forms of genetic conflict can potentially shape the evolution of genes on UV sex chromosomes, including sexual dimorphism, parent-offspring conflict, and meiotic sex-ratio distortion. Some evidence supports the action of each of these forms of conflict in species with UV systems. The prevalence of conflict is predicted to covary with the breeding system and genetic diversity, both of which vary considerably among bryophyte species (Eppley et al. 2007). Although work on genetic conflict in UV systems is in its infancy, it is clear the forms of conflict may act synergistically, through both increasing outbreeding levels and altering linkage patterns on the sex chromosomes. Here we specifically explore how the prevalence of genetic conflict may drive variation in sex chromosome content in bryophytes and other UV systems. 
Sexual dimorphism: Perhaps the most obvious reason for sex chromosomes to grow relates to their role in sexual dimorphism. Males and females achieve fitness through different strategies (Bateman 1948; Robert 1972; Lessells \& Parker 1999; Chapman 2006). Certainly, genes related to sex-limited functions like sperm or egg production are likely candidates for genes that could evolve sex linkage, although the number of genes that are directly involved in gamete production may be relatively modest and is probably similar among organisms. Nevertheless, anisogamy can generate selection for sexual dimorphism for a variety of additional traits between the sexes (Parker \& Others 1979; Bonduriansky et al. 2008).

The ubiquity of sexual dimorphism suggests selection frequently favors different trait optima in males and females. For example, females of the moss C. purpureus produce abundant volatile organic compounds (VOCs) while males produce much less (Rosenstiel et al. 2012). Remarkably, the female VOCs attract moss sperm-dispersing microarthopods (mites and springtails) in laboratory choice experiments, suggesting that VOC production is part of a scent-based fertilization syndrome analogous to flowering plant-pollinator mutualisms (Rosenstiel et al. 2012; Shortlidge et al. 2020). Co-cultivating mosses and arthropods can increase both the number of genotypes that reproduce and the overall number of sporophytes produced (Cronberg et al. 2006; Shortlidge et al. 2020). The fact that males have lower VOC production, however, suggests that scent production may be costly. Thus, a mutation that increases VOC production may be beneficial for females, but deleterious for males. This sexual antagonism can be resolved by evolving either sex-linkage (i.e., moving the genes for VOC production to the sex chromosome, where they can evolve to their sex-specific optima) or sex-biased gene expression, where the genes that control VOC production may be expressed in different ways in males and females (Vicoso \& Charlesworth 2006; Ellegren \& Parsch 2007). Sex-biased gene expression is very common in animals, but the relative importance of differential autosomal gene expression compared to sex linkage in UV systems is unknown. Although in C. purpureus, the abundant sex-linked genes are clearly important between the sexes (Carey et al. 2020).

Sexual dimorphism is found in a wide variety of other traits in bryophytes, suggesting that sexually antagonistic selection may drive the evolution of sex linkage. For example, leaf size and juvenile growth in C. purpureus are sexually dimorphic (McDaniel 2009) as are life history traits in the liverwort M. introflexa (McLetchie \& Puterbaugh 2000; Fuselier 2008) and the brown algae Ectocarpus (Lipinska et al. 2015). The links between such trait variation and either male or female fitness are less clear than for VOC production, but it remains a reasonable hypothesis that more dimorphic species, or species with stronger male-male competition or female-mate choice, may possess more sex-linked genes. We should point out that the relationship between dimorphism and sex chromosome gene content may not be entirely straight-forward - for example, several species of mosses, like the genera Dicranum and Homalothecium, possess an extreme form of sexual dimorphism in which dwarf males grow epiphytically on more typical sized females (Hedenäs \& Bisang 2011; Rosengren \& Cronberg 2014), a form of sexual dimorphism that may actually decrease male-male competition. Detailed studies relating the breeding system of a species to levels of sexual conflict are fertile areas for research in bryophyte biology.

Parent-offspring conflict over nutrient allocation: The fact that males and females differ in the amount of resources they allocate to reproduction also sets the stage for genomic conflict (Arnqvist \& Rowe 2005). Theory suggests conflict is particularly likely for species that provision offspring through vivipary (Zeh \& Zeh 2000). In embryophytes (i.e., land plants), the embryo is retained on the haploid, female gametophyte and water and nutrients are provided for a time through specialized transfer cells analogous to a placenta. The males, in contrast, have no role in providing for offspring after fertilization. A better provisioned embryo (sporophyte) is likely to make more and healthier spores, increasing the fitness of both the male and female. However, in species where the female can reproduce more than once, the allocation to one sporophyte may come at the expense of other sibling sporophytes (Stark et al. 2009). Therefore, female fitness is maximized by equal allocation to several offspring by modulating the transfer of nutrients across the placenta (Haig 2013). In contrast, a male may not mate with the same female again (nor any other female), so male fitness increases with every additional viable spore that an offspring sporophyte produces. Thus, paternal genes in the embryo are expected to evolve to extract as much of the female's resources as possible to promote spore production (Haig 2013). Consistent with this, studies in Funaria hygrometrica showed the maternal calyptra tissue that covers the offspring sporophyte, controls its growth (Bopp 1957; Budke 2019). Moreover, spore production in experimental crosses in $C$. purpureus suggest the genetic variation necessary for parent-offspring conflict is found in this species (Shortlidge et al. 2020). The same female crossed to two different males produced sporophytes that varied in spore production, suggesting the paternal genotype influences the transfer of nutrients across the placenta (Shortlidge et al. 2020). Interestingly, the difference between the interests of the maternal and paternal contributions becomes more intense as the levels of outbreeding increase (Haig 2010), again highlighting the importance of the breeding system for shaping genetic conflict. 
We expect that sex chromosomes may be enriched in genes that influence the flow of nutrients across the placenta from mother to offspring. In XY systems, only the degenerate Y chromosome shows sex-limited inheritance, potentially minimizing its role in parent-offspring conflict. However, autosomal genes that influence maternal transfer may have parent-of-origin effects depending upon whether they are transferred from the mother or father, an observation termed genomic imprinting (Reik \& Walter 2001). What is striking about UV systems is the unusual pattern of inheritance of the sex chromosomes accomplishes what other systems do by genomic imprinting. Because the $\mathrm{U}$ and $\mathrm{V}$ chromosomes do not recombine, their interests diverge considerably in the developing UV-heterozygous embryo, providing a highlyfavorable environment for the fixation of diploid-acting, sexually antagonistic alleles that influence the flow of nutrients from the maternal (U) gametophyte to the offspring (UV) sporophyte. The U-linked maternal genes within the embryo are genetically identical to its mother, and therefore share a common interest, but the V-linked paternal genes in the embryo may have different interests regarding the amount of offspring provisioning (Haig \& Wilczek 2006). Formal tests linking parent-offspring conflict to the expansion of UV sex chromosomes will likely involve a combination of placental transcriptomics, classical genetics, and transgenic approaches.

Sex-biased transmission ratio distortion: A final form of sexual antagonism that is common to all dioecious species with chromosomal sex determination is meiotic sex-ratio distortion. The meiotic sex ratio in a wide variety of eukaryotes deviates from the expected 1:1 segregation of males and females (Lyttle 1993). At meiosis, any allele that preferentially transmits itself to the next generation has an immediate benefit, thus selection on these loci can be very strong because such alleles consistently have higher frequency in offspring. In principle, any heterozygous locus could experience biased transmission (Haig 2010). Distorter alleles may bias transmission by a wide variety of mechanisms, but in UV systems distorters generally disable meiotic products carrying the alternate allele. Mutations that result in more female offspring are likely to arise on, or be inherited with the $\mathrm{U}$, while mutations that distort the sex ratio in favor of males will be associated with the $\mathrm{V}$.

Most meiotic sex-ratio distorter systems typically consist of multiple distinct genes (Werren \& Beukeboom 1998). Distorter systems require a killer locus that halts development or otherwise disables the products of meiosis, and a second locus that protects the distorting chromosome from being disabled (Bravo Núñez et al. 2018). Thus, a distorting $\mathrm{U}$ chromosome would have a killer allele and an allele at the second locus that disarms the killer, often termed an insensitive-responder allele. The V chromosome, in contrast, would lack the killer and would carry a linked, sensitiveresponder allele. Because the killer and insensitive-responder must be inherited together, genomic regions that lack meiotic recombination, like sex chromosomes, may be more likely to evolve distorter systems simply because they contain more genes that can potentially evolve the killing and resistance functions. As a meiotic killer system spreads, one sex could become rare, conditions that favor the evolution of alleles at a third locus that suppress the killer allele, restoring fertility (Tao et al. 2007). Although restorer alleles can arise on autosomes, the sex chromosomes are predicted to be hot-spots for the evolution of restorer alleles too (Hall 2004). Thus, because they contain large regions of suppressed recombination that have sex-limited inheritance, sex chromosomes are likely to accumulate multiple genes that influence the outcome of meiosis through either spore killing or fertility restoration.

A key difference between diploid and haploid mating systems is the action of a meiotic distorter in haploids most often will result in spore death (Nauta \& Hoekstra 1993). Because each spore directly contributes to forming the next generation of gametophytes, unlike sperm which contribute indirectly through fertilization of an egg, spore death causes a loss of fitness. Thus, the evolution of meiotic sex-ratio distorters is likely to be held in check by the fitness cost caused by spore killing, in addition to the reduction in mating opportunity caused by decreasing the frequency of one sex. Nevertheless, several spore killer systems segregate in fungi (e.g., Hammond et al. 2012) and variation in spore death in C. purpureus has a genetic basis (Shaw \& Gaughan 1993; McDaniel et al. 2007; Norrell et al. 2014). Numerous questions remain regarding the true fitness costs of meiotic sex-ratio distortion in bryophytes (and other organisms), life-history traits that promote the evolution of meiotic distorters, and the potential interactions among different forms of genetic conflict in shaping the gene content of the male and female sex chromosomes.

\section{The central role of natural history in evolutionary genomics}

In this review, we have argued that the wide variation in sex chromosome size and gene content may be explained by variation in levels of genetic conflict, and further that bryophytes provide the necessary variation to test this hypothesis. In UV systems, suppressed recombination is not confounded with sex-specific mutational biases, sexspecific inheritance, and sexual selection, making bryophytes well-suited for studying how conflicts affect both male 
and female sex chromosomes. Clearly this effort will be bolstered by sequencing additional bryophyte genomes, and we anticipate that soon we will have a clearer picture of the gene content and evolutionary history of an increasing number of UV sex chromosome systems. In addition, generating sex-linked markers will open numerous research avenues in many previously genetically intractable systems, enabling us to understand many sex-specific demographic phenomena (e.g., dispersal, growth, mating success, male-male competition, female-mate choice, biased mortality, or $N_{e}$ ), in addition to more effectively designing studies of sexual dimorphism, parent-offspring conflict, and meiotic sex-ratio variation.

Equally important, however, is the role that natural history and phylogenetics can play in contextualizing the results of genomic analyses. Life history features relating to patterns of mating in nature, in particular, may be central to modulating the role of genetic conflict in genome evolution. Bryophytes are one of the few terrestrial groups that contain large proportions of both hermaphrodites and species with separate sexes. This circumstance makes bryophytes unusually well-suited for linking sex chromosome history and molecular evolution to patterns of diversification. How often is speciation associated with a change in mating system? Are sex chromosomes more likely than autosomes to be exchanged among distant populations, or more likely to host loci that promote reproductive isolation? Does genetic conflict promote elevated rates of speciation (Crespi \& Nosil 2013), or extinction (Price et al. 2010; Werren 2011), and under what conditions? Critically, bryophytes possess underexplored life history and taxonomic variation that may be used to draw general solutions to key questions regarding the long-term evolution of sex chromosomes across eukaryotes.

\section{Acknowledgements}

We thank two anonymous reviewers for helpful feedback on this manuscript. SFM was supported by NSF-DEB grants 1541005 and 1542609.

\section{References}

Ahmed, S., Cock, J.M., Pessia, E., Luthringer, R., Cormier, A., Robuchon, M., Sterck, L., Peters, A.F., Dittami, S.M., Corre, E., Valero, M., Aury, J.-M., Roze, D., Van de Peer, Y., Bothwell, J., Marais, G.A.B. \& Coelho, S.M. (2014) A haploid system of sex determination in the brown alga Ectocarpus sp. Current biology 24 (17): 1945-1957.

https://doi.org/10.1016/j.cub.2014.07.042

Akagi, T., Henry, I.M., Tao, R. \& Comai, L. (2014) A Y-chromosome-encoded small RNA acts as a sex determinant in persimmons. Science 346 (6209): 646-650. https://doi.org/10.1126/science. 1257225

Allen, C.E. (1917) A chromosome difference correlated with sex differences in sphærocarpos. Science 46 (1193): $466-467$. https://doi.org/10.1126/science.46.1193.466

Allen, C.E. (1945) The genetics of bryophytes. II. The Botanical review; interpreting botanical progress 11 (5): $260-287$. https://doi.org/10.1007/BF02861195

Anderson, L.E. (2000) Charles E. Allen and Sex Chromosomes. The Bryologist 103 (3): 442-448. https://doi.org/10.1639/0007-2745(2000)103[0442:CEAASC]2.0.CO;2

Arnqvist, G. \& Rowe, L. (2005) Sexual Conflict. Princeton University Press, 330 pp. https://doi.org/10.1515/9781400850600

Avia, K., Lipinska, A.P., Mignerot, L., Montecinos, A.E., Jamy, M., Ahmed, S., Valero, M., Peters, A.F., Cock, J.M., Roze, D. \& Coelho, S.M. (2018) Genetic Diversity in the UV Sex Chromosomes of the Brown Alga Ectocarpus. Genes 9 (6): 286. https://doi.org/10.3390/genes9060286

Bachtrog, D., Kirkpatrick, M., Mank, J.E., McDaniel, S.F., Pires, J.C., Rice, W. \& Valenzuela, N. (2011) Are all sex chromosomes created equal? Trends in genetics: TIG 27 (9): 350-357. https://doi.org/10.1016/j.tig.2011.05.005

Bateman, A.J. (1948) Intra-sexual selection in Drosophila. Heredity 2 (Pt. 3): 349-368. https://doi.org/10.1038/hdy.1948.21 
Baughman, J.T., Payton, A.C., Paasch, A.E., Fisher, K.M. \& McDaniel, S.F. (2017) Multiple factors influence population sex ratios in the Mojave Desert moss Syntrichia caninervis. American journal of botany 104 (5): 733-742. https://doi.org/10.3732/ajb.1700045

Bazzicalupo, A.L., Carpentier, F., Otto, S.P. \& Giraud, T. (2019) Little Evidence of Antagonistic Selection in the Evolutionary Strata of Fungal Mating-Type Chromosomes (Microbotryum lychnidis-dioicae). G3 9 (6): 1987-1998. https://doi.org/10.1534/g3.119.400242

Begun, D.J. \& Aquadro, C.F. (1992) Levels of naturally occurring DNA polymorphism correlate with recombination rates in D. melanogaster. Nature 356 (6369): 519-520. https://doi.org/10.1038/356519a0

Bengtsson, B.O. \& Cronberg, N. (2009) The effective size of bryophyte populations. Journal of theoretical biology 258 (1): $121-126$. https://doi.org/10.1016/j.jtbi.2009.01.002

Berger, F. (2019) Emil Heitz, a true epigenetics pioneer. Nature reviews. Molecular cell biology 20 (10): 572. https://doi.org/10.1038/s41580-019-0161-z

Bonduriansky, R., Maklakov, A., Zajitschek, F. \& Brooks, R. (2008) Sexual Selection, Sexual Conflict and the Evolution of Ageing and Life Span. Functional ecology 22 (3): 443-453.

https://doi.org/10.1111/j.1365-2435.2008.01417.x

Bopp, M. (1957) Entwicklungsphysiologische Untersuchungen an Moosmutanten. Zeitschrift fur induktive Abstammungs-und Vererbungslehre 88 (4): 600-607. https://doi.org/10.1007/BF00309430

Bowman, J.L., Kohchi, T., Yamato, K.T., Jenkins, J., Shu, S., Ishizaki, K., Yamaoka, S., Nishihama, R., Nakamura, Y., Berger, F., Adam, C., Aki, S.S., Althoff, F., Araki, T., Arteaga-Vazquez, M.A., Balasubrmanian, S., Barry, K., Bauer, D., Boehm, C.R., Briginshaw, L., Caballero-Perez, J., Catarino, B., Chen, F., Chiyoda, S., Chovatia, M., Davies, K.M., Delmans, M., Demura, T., Dierschke, T., Dolan, L., Dorantes-Acosta, A.E., Eklund, D.M., Florent, S.N., Flores-Sandoval, E., Fujiyama, A., Fukuzawa, H., Galik, B., Grimanelli, D., Grimwood, J., Grossniklaus, U., Hamada, T., Haseloff, J., Hetherington, A.J., Higo, A., Hirakawa, Y., Hundley, H.N., Ikeda, Y., Inoue, K., Inoue, S.-I., Ishida, S., Jia, Q., Kakita, M., Kanazawa, T., Kawai, Y., Kawashima, T., Kennedy, M., Kinose, K., Kinoshita, T., Kohara, Y., Koide, E., Komatsu, K., Kopischke, S., Kubo, M., Kyozuka, J., Lagercrantz, U., Lin, S.-S., Lindquist, E., Lipzen, A.M., Lu, C.-W., De Luna, E., Martienssen, R.A., Minamino, N., Mizutani, M., Mizutani, M., Mochizuki, N., Monte, I., Mosher, R., Nagasaki, H., Nakagami, H., Naramoto, S., Nishitani, K., Ohtani, M., Okamoto, T., Okumura, M., Phillips, J., Pollak, B., Reinders, A., Rövekamp, M., Sano, R., Sawa, S., Schmid, M.W., Shirakawa, M., Solano, R., Spunde, A., Suetsugu, N., Sugano, S., Sugiyama, A., Sun, R., Suzuki, Y., Takenaka, M., Takezawa, D., Tomogane, H., Tsuzuki, M., Ueda, T., Umeda, M., Ward, J.M., Watanabe, Y., Yazaki, K., Yokoyama, R., Yoshitake, Y., Yotsui, I., Zachgo, S. \& Schmutz, J. (2017) Insights into Land Plant Evolution Garnered from the Marchantia polymorpha Genome. Cell 171 (2): 287-304.

https://doi.org/10.1016/j.cell.2017.09.030

Branco, S., Badouin, H., Rodríguez, de la Vega, R.C., Gouzy, J., Carpentier, F., Aguileta, G., Siguenza, S., Brandenburg, J.-T., Coelho, M.A., Hood, M.E. \& Giraud, T. (2017) Evolutionary strata on young mating-type chromosomes despite the lack of sexual antagonism. Proceedings of the National Academy of Sciences of the United States of America 114 (27): 7067-7072.

https://doi.org/10.1073/pnas.1701658114

Bravo Núñez, M.A., Nuckolls, N.L. \& Zanders, S.E. (2018) Genetic Villains: Killer Meiotic Drivers. Trends in genetics 34 (6): $424-433$. https://doi.org/10.1016/j.tig.2018.02.003

Budke, J.M. (2019) The moss calyptra: A maternal structure influencing offspring development. The Bryologist 122 (3): $471-491$. https://doi.org/10.1639/0007-2745-122.3.471

Bull, J.J. (1983) Evolution of sex determining mechanisms. The Benjamin/Cummings Publishing Company, Inc.

Carey, S.B., Jenkins, J., Payton, A.C., Shu, S., Lovell, J.T., Maumus, F., Sreedasyam, A., Tiley, G.P., Fernandez-Pozo, N., Barry, K., Chen, C., Wang, M., Lipzen, A., Daum, C., Saski, C.A., McBreen, J.C., Conrad, R.E., Kollar, L.M., Olsson, S., Huttunen, S., Landis, J.B., Gordon Burleigh, J., Wickett, N.J., Johnson, M.G., Rensing, S.A., Grimwood, J., Schmutz, J. \& McDaniel, S.F. (2020) Chromosome fusions shape an ancient UV sex chromosome system. bioRxiv.

https://doi.org/10.1101/2020.07.03.163634

Chapman, T. (2006) Evolutionary conflicts of interest between males and females. Current biology 16 (17): R744-54. https://doi.org/10.1016/j.cub.2006.08.020

Charlesworth, B. \& Charlesworth, D. (1978) A model for the evolution of dioecy and gynodioecy. The American naturalist 112. https://doi.org/10.1086/283342

Charlesworth, B. (2009) Effective population size and patterns of molecular evolution and variation. Nature reviews. Genetics 10 (3): 195-205.

https://doi.org/10.1038/nrg2526 
Charlesworth, B. \& Charlesworth, D. (2000) The degeneration of Y chromosomes. Philosophical transactions of the Royal Society of London. Series B, Biological sciences 355 (1403): 1563-1572.

https://doi.org/10.1098/rstb.2000.0717

Coelho, S.M., Gueno, J., Lipinska, A.P., Cock, J.M. \& Umen, J.G. (2018) UV Chromosomes and Haploid Sexual Systems. Trends in plant science 23 (9): 794-807.

https://doi.org/10.1016/j.tplants.2018.06.005

Comeron, J.M., Williford, A. \& Kliman, R.M. (2008) The Hill-Robertson effect: evolutionary consequences of weak selection and linkage in finite populations. Heredity 100 (1): 19-31. https://doi.org/10.1038/sj.hdy.6801059

Crespi, B. \& Nosil, P. (2013) Conflictual speciation: species formation via genomic conflict. Trends in ecology \& evolution 28 (1): $48-57$. https://doi.org/10.1016/j.tree.2012.08.015

Cronberg, N., Natcheva, R. \& Hedlund, K. (2006) Microarthropods mediate sperm transfer in mosses. Science 313 (5791): 1255. https://doi.org/10.1126/science.1128707

De Clerck, O., Kao, S.-M., Bogaert, K.A., Blomme, J., Foflonker, F., Kwantes, M., Vancaester, E., Vanderstraeten, L., Aydogdu, E., Boesger, J., Califano, G., Charrier, B., Clewes, R., Del Cortona, A., D’Hondt, S., Fernandez-Pozo, N., Gachon, C.M., Hanikenne, M., Lattermann, L., Leliaert, F., Liu, X., Maggs, C.A., Popper, Z.A., Raven, J.A., Van Bel, M., Wilhelmsson, P.K.I., Bhattacharya, D., Coates, J.C., Rensing, S.A., Van Der Straeten, D., Vardi, A., Sterck, L., Vandepoele, K., Van de Peer, Y., Wichard, T. \& Bothwell, J.H. (2018) Insights into the Evolution of Multicellularity from the Sea Lettuce Genome. Current biology 28 (18): 2921-2933. https://doi.org/10.1016/j.cub.2018.08.015

Dufaÿ, M., Champelovier, P., Käfer, J., Henry, J.-P., Mousset, S. \& Marais, G.A.B. (2014) An angiosperm-wide analysis of the gynodioecy-dioecy pathway. Annals of botany 114 (3): 539-548. https://doi.org/10.1093/aob/mcu134

Ellegren, H. \& Parsch, J. (2007) The evolution of sex-biased genes and sex-biased gene expression. Nature reviews. Genetics 8 (9): 689-698. https://doi.org/10.1038/nrg2167

Eppley, S.M., Taylor, P.J. \& Jesson, L.K. (2007) Self-fertilization in mosses: a comparison of heterozygote deficiency between species with combined versus separate sexes. Heredity 98 (1): 38-44. https://doi.org/10.1038/sj.hdy.6800900

Ferris, P., Olson, B.J.S.C., De Hoff, P.L., Douglass, S., Casero, D., Prochnik, S., Geng, S., Rai, R., Grimwood, J., Schmutz, J., Nishii, I., Hamaji, T., Nozaki, H., Pellegrini, M. \& Umen, J.G. (2010) Evolution of an expanded sex-determining locus in Volvox. Science 328 (5976): 351-354. https://doi.org/10.1126/science.1186222

Furman, B.L.S., Metzger, D.C.H., Darolti, I., Wright, A.E., Sandkam, B.A., Almeida, P., Shu, J.J. \& Mank, J.E. (2020) Sex Chromosome Evolution: So Many Exceptions to the Rules. Genome biology and evolution 12 (6): 750-763. https://doi.org/10.1093/gbe/evaa081

Fuselier, L. (2008) Variation in life history characteristics between asexual and sexual populations of marchantia inflexa. The Bryologist 111 (2): 248-259. https://doi.org/10.1639/0007-2745(2008)111[248:VILHCB]2.0.CO;2

Guillemin, M.-L., Huanel, O.R. \& Martínez, E.A. (2012) Characterization of genetic markers linked to sex determination in the haploiddiploid red alga gracilaria chilensis. Journal of phycology 48 (2): 365-372. https://doi.org/10.1111/j.1529-8817.2012.01116.x

Haig, D. (2013) Filial mistletoes: the functional morphology of moss sporophytes. Annals of botany 111 (3): 337-345. https://doi.org/10.1093/aob/mcs295

Haig, D. (2010) Games in tetrads: segregation, recombination, and meiotic drive. The American naturalist 176 (4): $404-413$. https://doi.org/10.1086/656265

Haig, D. \& Wilczek, A. (2006) Sexual conflict and the alternation of haploid and diploid generations. Philosophical transactions of the Royal Society of London. Series B, Biological sciences 361 (1466): 335-343. https://doi.org/10.1098/rstb.2005.1794

Hall, D.W. (2004) Meiotic drive and sex chromosome cycling. Evolution; international journal of organic evolution 58 (5): $925-931$. https://doi.org/10.1111/j.0014-3820.2004.tb00426.x

Hamaji, T., Mogi, Y., Ferris, P.J., Mori, T., Miyagishima, S., Kabeya, Y., Nishimura, Y., Toyoda, A., Noguchi, H., Fujiyama, A., Olson, B.J.S.C., Marriage, T.N., Nishii, I., Umen, J.G. \& Nozaki, H. (2016) Sequence of the Gonium pectorale Mating Locus Reveals a Complex and Dynamic History of Changes in Volvocine Algal Mating Haplotypes. G3 6 (5): 1179-1189. 
https://doi.org/10.1534/g3.115.026229

Hammond, T.M., Rehard, D.G., Xiao, H. \& Shiu, P.K.T. (2012) Molecular dissection of Neurospora Spore killer meiotic drive elements. Proceedings of the National Academy of Sciences of the United States of America 109 (30): 12093-12098. https://doi.org/10.1073/pnas.1203267109

Hedenäs, L. \& Bisang, I. (2011) The overlooked dwarf males in mosses-Unique among green land plants. Perspectives in plant ecology, evolution and systematics 13 (2): 121-135. https://doi.org/10.1016/j.ppees.2011.03.001

Heitz, E. (1928) Das heterochromatin der moose.Bornträger.

Herron, M.D., Hackett, J.D., Aylward, F.O. \& Michod, R.E. (2009) Triassic origin and early radiation of multicellular volvocine algae. Proceedings of the National Academy of Sciences of the United States of America 106 (9): 3254-3258. https://doi.org/10.1073/pnas.0811205106

Hough, J., Wang, W., Barrett, S.C.H. \& Wright, S.I. (2017) Hill-Robertson Interference Reduces Genetic Diversity on a Young Plant YChromosome. Genetics 207 (2): 685-695. https://doi.org/10.1534/genetics.117.300142

Immler, S. \& Otto, S.P. (2015) The evolution of sex chromosomes in organisms with separate haploid sexes. Evolution; international journal of organic evolution 69 (3): 694-708. https://doi.org/10.1111/evo.12602

Ironside, J.E. (2010) No amicable divorce? Challenging the notion that sexual antagonism drives sex chromosome evolution. BioEssays: news and reviews in molecular, cellular and developmental biology 32 (8): 718-726. https://doi.org/10.1002/bies.200900124

Korpelainen, H., Bisang, I., Hedenäs, L. \& Kolehmainen, J. (2008) The first sex-specific molecular marker discovered in the moss Pseudocalliergon trifarium. The Journal of heredity 99 (6): 581-587. https://doi.org/10.1093/jhered/esn036

Laenen, B., Machac, A., Gradstein, S.R., Shaw, B., Patiño, J., Désamoré, A., Goffinet, B., Cox, C.J., Shaw, A.J. \& Vanderpoorten, A. (2016) Increased diversification rates follow shifts to bisexuality in liverworts. The New phytologist 210 (3): 1121-1129. https://doi.org/10.1111/nph.13835

Lessells, C.M. \& Parker, G.A. (1999) Parent—offspring conflict: the full-sib-half-sib fallacy. Proceedings of the Royal Society of London. Series B: Biological Sciences 266 (1429): 1637-1643. https://doi.org/10.1098/rspb.1999.0826

Lipinska, A., Cormier, A., Luthringer, R., Peters, A.F., Corre, E., Gachon, C.M.M., Cock, J.M. \& Coelho, S.M. (2015) Sexual dimorphism and the evolution of sex-biased gene expression in the brown alga ectocarpus. Molecular biology and evolution 32 (6): 1581-1597. https://doi.org/10.1093/molbev/msv049

Lipinska, A.P., Toda, N.R.T., Heesch, S., Peters, A.F., Cock, J.M. \& Coelho, S.M. (2017) Multiple gene movements into and out of haploid sex chromosomes. Genome biology 18 (1): 104. https://doi.org/10.1186/s13059-017-1201-7

Luthringer, R., Cormier, A., Ahmed, S., Peters, A.F., Cock, J.M. \& Coelho, S.M. (2014) Sexual dimorphism in the brown algae. Perspectives in Phycology 1 (1): 11-25. https://doi.org/10.1127/2198-011X/2014/0002

Luthringer, R., Lipinska, A.P., Roze, D., Cormier, A., Macaisne, N., Peters, A.F., Cock, J.M. \& Coelho, S.M. (2015) The Pseudoautosomal Regions of the U/V Sex Chromosomes of the Brown Alga Ectocarpus Exhibit Unusual Features. Molecular biology and evolution 32 (11): 2973-2985.

https://doi.org/10.1093/molbev/msv173

Lyttle, T.W. (1993) Cheaters sometimes prosper: distortion of mendelian segregation by meiotic drive. Trends in genetics 9 (6): 205210. https://doi.org/10.1016/0168-9525(93)90120-7

Mank, J.E. (2013) Sex chromosome dosage compensation: definitely not for everyone. Trends in genetics 29 (12): $677-683$. https://doi.org/10.1016/j.tig.2013.07.005

McDaniel, S.F. (2009) The Genetic Basis of Natural Variation in Bryophyte Model Systems, In: Roberts J.A. (Ed.) Annual Plant Reviews online, Vol. 46. John Wiley \& Sons, Ltd. Chichester, UK, pp. 16-41. https://doi.org/10.1002/9781119312994.apr0385

McDaniel, S.F., Atwood, J. \& Burleigh, J.G. (2013) Recurrent evolution of dioecy in bryophytes. Evolution; international journal of organic evolution 67 (2): 567-572.

https://doi.org/10.1111/j.1558-5646.2012.01808.x 
McDaniel, S.F., Neubig, K.M., Payton, A.C., Quatrano, R.S. \& Cove, D.J. (2013) Recent gene-capture on the uv sex chromosomes of the moss ceratodon purpureus. Evolution 67 (10): 2811-2822. https://doi.org/10.1111/evo.12165

McDaniel, S.F. \& Perroud, P.-F. (2012) Invited perspective: bryophytes as models for understanding the evolution of sexual systems. The Bryologist 115 (1): 1-11.

https://doi.org/10.1639/0007-2745-115.1.1

McDaniel, S.F., Willis, J.H. \& Shaw, A.J. (2007) A linkage map reveals a complex basis for segregation distortion in an interpopulation cross in the moss Ceratodon purpureus. Genetics 176 (4): 2489-2500. https://doi.org/10.1534/genetics.107.075424

McLetchie, D.N. \& Puterbaugh, M.N. (2000) Population sex ratios, sex-specific clonal traits and tradeoffs among these traits in the liverwort Marchantia inflexa. Oikos 90 (2): 227-237. https://doi.org/10.1034/j.1600-0706.2000.900203.x

Montgomery, S.A., Tanizawa, Y., Galik, B., Wang, N., Ito, T., Mochizuki, T., Akimcheva, S., Bowman, J.L., Cognat, V., Maréchal-Drouard, L., Ekker, H., Hong, S.-F., Kohchi, T., Lin, S.-S., Liu, L.-Y.D., Nakamura, Y., Valeeva, L.R., Shakirov, E.V., Shippen, D.E., Wei, W.-L., Yagura, M., Yamaoka, S., Yamato, K.T., Liu, C. \& Berger, F. (2020) Chromatin Organization in Early Land Plants Reveals an Ancestral Association between H3K27me3, Transposons, and Constitutive Heterochromatin. Current biology 30 (4): $573-588$. https://doi.org/10.1016/j.cub.2019.12.015

Muller, H.J. (1932) Some Genetic Aspects of Sex. The American naturalist 66 (703): 118-138. https://doi.org/10.1086/280418

Müller, N.A., Kersten, B., Leite Montalvão, A.P., Mähler, N., Bernhardsson, C., Bräutigam, K., Carracedo Lorenzo, Z., Hoenicka, H., Kumar, V., Mader, M., Pakull, B., Robinson, K.M., Sabatti, M., Vettori, C., Ingvarsson, P.K., Cronk, Q., Street, N.R. \& Fladung, M. (2020) A single gene underlies the dynamic evolution of poplar sex determination. Nature plants 6 (6): 630-637. https://doi.org/10.1038/s41477-020-0672-9

Nauta, M.J. \& Hoekstra, R.F. (1993) Evolutionary dynamics of spore killers. Genetics 135 (3): 923-930. https://doi.org/10.1093/genetics/135.3.923

Norrell, T.E., Jones, K.S., Payton, A.C. \& McDaniel, S.F. (2014) Meiotic sex ratio variation in natural populations of Ceratodon purpureus (Ditrichaceae). American journal of botany 101 (9): 1572-1576. https://doi.org/10.3732/ajb.1400156

Okada, S., Sone, T., Fujisawa, M., Nakayama, S., Takenaka, M., Ishizaki, K., Kono, K., Shimizu-Ueda, Y., Hanajiri, T., Yamato, K.T., Fukuzawa, H., Brennicke, A. \& Ohyama, K. (2001) The Y chromosome in the liverwort Marchantia polymorpha has accumulated unique repeat sequences harboring a male-specific gene. Proceedings of the National Academy of Sciences of the United States of America 98 (16): 9454-9459. https://doi.org/10.1073/pnas.171304798

Otto, S.P., Pannell, J.R., Peichel, C.L., Ashman, T.-L., Charlesworth, D., Chippindale, A.K., Delph, L.F., Guerrero, R.F., Scarpino, S.V. \& McAllister, B.F. (2011) About PAR: the distinct evolutionary dynamics of the pseudoautosomal region. Trends in genetics 27 (9): $358-367$. https://doi.org/10.1016/j.tig.2011.05.001

Parker, G.A. \& Others (1979) Sexual selection and sexual conflict. Sexual selection and reproductive competition in insects $123: 166$. https://doi.org/10.1016/B978-0-12-108750-0.50010-0

Price, T.A.R., Hurst, G.D.D. \& Wedell, N. (2010) Polyandry prevents extinction. Current biology 20 (5): 471-475. https://doi.org/10.1016/j.cub.2010.01.050

Reik, W. \& Walter, J. (2001) Genomic imprinting: parental influence on the genome. Nature reviews. Genetics 2 (1): $21-32$. https://doi.org/10.1038/35047554

Renner, S.S. (2014) The relative and absolute frequencies of angiosperm sexual systems: dioecy, monoecy, gynodioecy, and an updated online database. American journal of botany 101 (10): 1588-1596. https://doi.org/10.3732/ajb.1400196

Renner, S.S., Heinrichs, J. \& Sousa, A. (2017) The sex chromosomes of bryophytes: Recent insights, open questions, and reinvestigations of Frullania dilatata and Plagiochila asplenioides. Journal of Systematics and Evolution 55 (4): 333-339. https://doi.org/10.1111/jse.12266

Reski, R. (1998) Development, Genetics and Molecular Biology of Mosses. Botanica acta: Berichte der Deutschen Botanischen Gesellschaft = journal of the German Botanical Society 111 (1): 1-15. https://doi.org/10.1111/j.1438-8677.1998.tb00670.x 
Rice, W.R. (1987) The Accumulation of Sexually Antagonistic Genes as a Selective Agent Promoting the Evolution of Reduced Recombination between Primitive Sex Chromosomes. Evolution; international journal of organic evolution 41 (4): 911-914. https://doi.org/10.2307/2408899

Robert, T. (1972) Parental investment and sexual selection. Sexual Selection \& the Descent of Man, Aldine de Gruyter, New York:, pp. $136-179$.

Rosengren, F. \& Cronberg, N. (2014) The adaptive background of nannandry: dwarf male distribution and fertilization in the moss Homalothecium lutescens. Biological journal of the Linnean Society. Linnean Society of London 113 (1): 74-84. https://doi.org/10.1111/bij.12332

Rosenstiel, T.N., Shortlidge, E.E., Melnychenko, A.N., Pankow, J.F. \& Eppley, S.M. (2012) Sex-specific volatile compounds influence microarthropod-mediated fertilization of moss. Nature 489 (7416): 431-433. https://doi.org/10.1038/nature11330

Sayres, M.A.W. (2018) Genetic diversity on the sex chromosomes. Genome biology and evolution 10 (4): 1064. https://doi.org/10.1093/gbe/evy039

Shaw, A.J. \& Gaughan, J.F. (1993) Control of sex ratios in haploid populations of the moss, ceratodon purpureus. American journal of botany 80 (5): 584-591. https://doi.org/10.1002/j.1537-2197.1993.tb13844.x

Shortlidge, E.E., Payton, A.C., Carey, S.B., McDaniel, S.F., Rosenstiel, T.N. \& Eppley, S.M. (2020) Microarthropod contributions to fitness variation in the common moss Ceratodon purpureus. bioRxiv. [Online] https://doi.org/10.1101/2020.12.02.408872

Stark, L.R., Brinda, J.C. \& McLetchie, D.N. (2009) An experimental demonstration of the cost of sex and a potential resource limitation on reproduction in the moss Pterygoneurum (Pottiaceae). American journal of botany 96 (9): 1712-1721. https://doi.org/10.3732/ajb.0900084

Szövényi, P., Perroud, P.-F., Symeonidi, A., Stevenson, S., Quatrano, R.S., Rensing, S.A., Cuming, A.C. \& McDaniel, S.F. (2015) De novo assembly and comparative analysis of the Ceratodon purpureus transcriptome. Molecular ecology resources 15 (1): $203-215$. https://doi.org/10.1111/1755-0998.12284

Tao, Y., Araripe, L., Kingan, S.B., Ke, Y., Xiao, H. \& Hartl, D.L. (2007) A sex-ratio meiotic drive system in Drosophila simulans. II: an X-linked distorter. PLoS biology 5 (11): e293. https://doi.org/10.1371/journal.pbio.0050293

Tree of Sex Consortium (2014) Tree of Sex: A database of sexual systems. Scientific Data: 1. https://doi.org/10.1038/sdata.2014.15

Vicoso, B. (2019) Molecular and evolutionary dynamics of animal sex-chromosome turnover. Nature ecology \& evolution 3 (12): 16321641. https://doi.org/10.1038/s41559-019-1050-8

Vicoso, B. \& Charlesworth, B. (2006) Evolution on the X chromosome: unusual patterns and processes. Nature reviews. Genetics 7 (8): 645-653. https://doi.org/10.1038/nrg1914

Villarreal, J.C. \& Renner, S.S. (2013) Correlates of monoicy and dioicy in hornworts, the apparent sister group to vascular plants. BMC evolutionary biology 13: 239. https://doi.org/10.1186/1471-2148-13-239

Voglmayr, H. (2000) Nuclear DNA Amounts in Mosses (Musci). Annals of botany 85 (4): 531-546. https://doi.org/10.1006/anbo.1999.1103

Werren, J.H. (2011) Selfish genetic elements, genetic conflict, and evolutionary innovation. Proceedings of the National Academy of Sciences of the United States of America 108 Suppl 2: 10863-10870. https://doi.org/10.1073/pnas.1102343108

Werren, J.H. \& Beukeboom, L.W. (1998) Sex determination, sex ratios, and genetic conflict. Annual review of ecology and systematics 29 (1): 233-261. https://doi.org/10.1146/annurev.ecolsys.29.1.233

Westergaard, M. (1958) The mechanism of sex determination in dioecious flowering plants. Advances in genetics 9: 217-281. https://doi.org/10.1016/S0065-2660(08)60163-7

Yamato, K.T., Ishizaki, K., Fujisawa, M., Okada, S., Nakayama, S., Fujishita, M., Bando, H., Yodoya, K., Hayashi, K., Bando, T., Hasumi, A., Nishio, T., Sakata, R., Yamamoto, M., Yamaki, A., Kajikawa, M., Yamano, T., Nishide, T., Choi, S.-H., Shimizu-Ueda, Y., Hanajiri, T., Sakaida, M., Kono, K., Takenaka, M., Yamaoka, S., Kuriyama, C., Kohzu, Y., Nishida, H., Brennicke, A., Shin-i, T., Kohara, Y., Kohchi, T., Fukuzawa, H. \& Ohyama, K. (2007) Gene organization of the liverwort Y chromosome reveals distinct sex chromosome evolution in a haploid system. Proceedings of the National Academy of Sciences 104 (15): 6472-6477. 
https://doi.org/10.1073/pnas.0609054104

Yamazaki, T., Ichihara, K., Suzuki, R., Oshima, K., Miyamura, S., Kuwano, K., Toyoda, A., Suzuki, Y., Sugano, S., Hattori, M. \& Kawano, S. (2017) Genomic structure and evolution of the mating type locus in the green seaweed Ulva partita. Scientific reports 7 (1): 11679.

https://doi.org/10.1038/s41598-017-11677-0

Zeh, D.W. \& Zeh, J.A. (2000) Reproductive mode and speciation: the viviparity-driven conflict hypothesis. BioEssays: news and reviews in molecular, cellular and developmental biology 22 (10): 938-946.

https://doi.org/10.1002/1521-1878(200010)22:10<938::AID-BIES9>3.0.CO;2-9 